\title{
Phylogenetic structure is determined by patch size in rock outcrop vegetation on an inselberg in the northern Amazon region
}

\author{
Pedro Manuel VILLA ${ }^{1,2,3^{*}}$, Markus GASTAUER ${ }^{4}$, Sebastião Venâncio MARTINS ${ }^{1,2}$; \\ Juan Fernando CARRIÓN ${ }^{5}$, Prímula Viana CAMPOS ${ }^{1}$, Alice Cristina RODRIGUES ${ }^{1,3,6}$, \\ Gustavo HERINGER ${ }^{1,3,6}$, João Augusto Alves MEIRA-NETO 1,6 \\ Universidade Federal de Viçosa, Programa de Pós-Graduação em Botânica, 36570-900, Viçosa, Minas Gerais, Brazil \\ Universidade Federal de Viçosa, Departamento de Engenharia Florestal, Laboratório de Restauração Florestal, 36570-900, Viçosa, Minas Gerais, Brazil \\ 3 Fundación para la Conservación de la Biodiversidad, 7101, Puerto Ayacucho, Amazonas, Venezuela \\ ${ }^{4}$ Instituto Tecnológico Vale, Rua Boaventura da Silva, 955, 66055-093, Belém, Pará, Brazil \\ Universidade Estadual de Feira de Santana, Av. Transnordestina, s/n, 44036-900, Feira de Santana, Bahia, Brazil \\ ${ }^{6}$ Universidade Federal de Viçosa, Departamento de Biologia Vegetal, Laboratório de Ecologia e Evolução de Plantas, 36570-900, Viçosa, Minas Gerais, Brazil \\ * Corresponding author: pedro.villa@ufv.br
}

\begin{abstract}
Although inselbergs from around the world are iconic ecosystems, little is known on the underlying mechanisms of community assembly, especially in their characteristic patchy outcrop vegetation. Environmental constraints are expected to cause phylogenetic clustering when ecological niches are conserved within evolutionary lineages. We tested whether vegetation patches from rock outcrops of the Piedra La Tortuga Natural Monument, in the northern Amazon region, are phylogenetically clustered, indicating that environmental filtering is the dominant driver of community assemblage therein. We classified all patches according to their size as very small $\left(<1 \mathrm{~m}^{2}\right)$, small $\left(1-4 \mathrm{~m}^{2}\right)$, medium-sized $\left(4-8 \mathrm{~m}^{2}\right)$, and large patches $\left(8-15 \mathrm{~m}^{2}\right)$. From each class, we randomly selected 10 patches, totalizing 40 patches covering $226 \mathrm{~m}^{2}$. All individuals found in the 40 isolated patches were identified to the species level. We also correlated measurements of phylogenetic community structure with patch size. We found that species from patches are restricted to the clades monocots, fabids, malvids, and lamiids. We conclude that vegetation in this rock outcrop is phylogenetically clustered. Furthermore, we found that phylogenetic turnover between pairs of patches increases with patch size, which is consistent with a scenario of higher environmental stress in smaller patches. Further research is necessary to identify nurse species in inselberg vegetation, which is pivotal for conservation and restoration of this particular ecosystem.
\end{abstract}

KEYWORDS: environmental filtering, phylogenetic turnover, phylogenetic clustering, phylogenetic diversity

\section{Estrutura filogenética é determinada pelo tamanho de manchas de vegetação sobre afloramento rochoso em um inselberg na região norte da Amazônia}

\section{RESUMO}

Ainda que os inselbergs ao redor do mundo sejam ecossistemas icônicos, pouco se sabe sobre os mecanismos subjacentes que estruturam suas comunidades vegetais, especialmente nas manchas de vegetação sobre afloramentos rochosos. Espera-se que as restriçôes ambientais causem agrupamento filogenético quando os nichos ecológicos são conservados dentro das linhagens evolutivas. Nós testamos se as manchas de vegetação dos afloramentos rochosos do Monumento Natural Piedra La Tortuga, no norte da região amazônica, apresentam indicadores filogenéticos de que a filtragem ambiental é o principal direcionador da estruturaçâo da comunidade. Classificamos todas as manchas de acordo com seu tamanho como muito pequenas $\left(<1 \mathrm{~m}^{2}\right)$, pequenas $\left(1-4 \mathrm{~m}^{2}\right)$, médias $\left(4-8 \mathrm{~m}^{2}\right)$ e grandes $\left(8-15 \mathrm{~m}^{2}\right)$. Selecionamos aleatoriamente 10 manchas em cada classe de tamanho, totalizando 40 manchas cobrindo $226 \mathrm{~m}^{2}$. Todos os indivíduos encontrados nas 40 manchas foram identificados ao nível de espécie. Correlacionamos as medidas da estrutura filogenética da comunidade com o tamanho das manchas e encontramos que as espécies das manchas são restritas aos clados das monocotiledôneas, fabídeas, malvídeas e lamiídeas. Concluímos que a vegetação neste afloramento rochoso é agrupada filogeneticamente. Além disso, encontramos que o turnover filogenético entre pares de manchas aumenta com o tamanho da mancha, o que é consistente com um cenário de alto estresse ambiental nas manchas menores. São necessárias mais pesquisas para identificar espécies facilitadoras, que são fundamentais para a conservação e restauração destes ecossistemas.

PALAVRAS-CHAVE: agrupamento filogenético, diversidade filogenética, filtro ambiental, turnover filogenético

CITE AS: Villa, P. M.; Gastauer, M.; Martins, S. V.; Carrión, J. F.; Campos, P. V.; Rodrigues, A. C.; Heringer, G.; Meira-Neto, J. A. A. 2018. Phylogenetic structure is determined by patch size in rock outcrop vegetation on an inselberg in the northern Amazon region. Acta Amazonica 48: $248-256$. 


\section{INTRODUCTION}

Inselbergs from all over the world are iconic rock outcrops that stand out abruptly from surrounding plains, being considered terrestrial islands due to their isolated position (Porembski and Barthlott 2000). High diversity, especially due to the presence of rare lifeforms (Seine et al. 1995; Porembski and Barthlott 2000; Greilhuber et al. 2008), and high degrees of endemism (Bussell and James 1997; Gröger 2000; Vogiatzakis et al. 2009; Jocque et al. 2010) predominantly characterize patchy vegetation formations (Aguiar and Gaglianone 2011; Porembski 2007; Pessanha et al. 2014). This is in direct contrast with the high levels of environmental stress to which these ecosystems are subjected, including reduced water and nutrient availability, and shallow soils (Gröger and Huber 2007; Porembski 2007). Despite their importance for biodiversity conservation, rock outcrops worldwide are endangered (de Paula et al. 2015; Porembski et al. 2016). To unravel the importance of biological interactions, as well as of environmental constraints, for community assembly, it is necessary to increase conservation and restoration activities on these unique ecosystems.

Environmental constraints such as low nutrient or water availability, high radiation, and large temperature amplitudes, as observed in rock outcrops of inselbergs, select for individuals possessing certain adaptive traits (Simberloff 1970; Gröger 2000; Porembski 2007; Kraft et al. 2015). Thereby, whenever ecological niches are conserved within evolutionary niches, phylogenetically related species share more functional traits and show higher niche overlap than what would be expected in a scenario driven by chance. In that case, environmental filtering triggers the coexistence of more evolutionarily related species than when species are under random assemblage, which characterizes phylogenetic clustering (Webb et al. 2002; Hardy and Jost 2008; Cianciaruso et al. 2009; Silva et al. 2011). In contrast, it is worth noting that inselbergs may present different habitat types along complex environmental gradients (Porembski 2007; Sarthou $e t$ al. 2009), and therefore an effect of habitat characteristics on the phylogenetic structure (i.e., patch size on rock outcrops) and assembly of communities is also to be expected.

In harsh, resource-limited ecosystems, patchy vegetation emerges due to the primacy of facilitation (Pugnaire and Lázaro 2000; Bowker and Maestre 2012). However, the manner in which this type of community is structured on inselbergs, especially in light of the effect that patch size probably has on resource availability, remains unknown. Therefore, patch size on inselbergs can cause a positive feedback between vegetation and resources, where nurse species increase growth performance of facilitated plants by microclimatic enhancement, e.g., reducing temperature and increasing soil moisture by shading (Sarthou et al. 2009; McIntire and Fajardo 2014; García-Cervigón et al. 2015), nutrient transfer (Stachowicz 2001), or protection against herbivores (Bruno et al. 2003). In that sense, it has been recently demonstrated that facilitation promotes higher species richness, higher phylogenetic diversity, and higher phylogenetic evenness (Valiente-Banuet and Verdú 2013; Winemiller et al. 2015), in order to avoid niche overlap between nurse and facilitated species (Carrión et al. 2017). For that reason, less phylogenetic clustering is expected in larger patches.

We aimed to evaluate the effect of patch size on the phylogenetic structure of a plant community on an inselberg in Piedra La Tortuga Natural Monument, in the northern Amazon region. We hypothesize that the plant community in the inselberg is phylogenetically clustered, indicating that environmental filtering is the dominant driver of the community assemblage. We correlated measures of phylogenetic community structure and phylogenetic turnover with patch size to test whether patch size is able to explain community assembly. Although this study was performed on a single inselberg, it is worth noting that the Piedra La Tortuga Natural Monument is a major center of endemism, and is one of the few protected areas in the entire Guayana Region (Venezuela), in the northern Amazon region (Huber, 1995). This is the first study on the phylogenetic community structure and phylogenetic turnover in a tropical inselberg.

\section{MATERIAL AND METHODS}

\section{Study area}

The study was carried out at the Piedra La Tortuga Natural Monument, which is an inselberg located on the right bank of the Orinoco River (5³3'46”N, 67³5'34”W, $90 \mathrm{~m}$ altitude), in the Amazonas State, Venezuela, in the northern Amazon region (Figure 1). The inselberg is inserted in a tropical dry forest matrix (Gröger 2000). Precipitation is highest between May and August, while a markedly dry period occurs between December and March. Mean annual precipitation is about $2,200 \mathrm{~mm}$, and mean temperature is approximately $26^{\circ} \mathrm{C}$ (Gröger and Huber 2007).

\section{Data collection}

To guarantee that all plant species were sampled, including ephemeral species that disappear during the dry period, vegetation patches from rock outcrops were sampled during the rainy period. We classified all patches according to their size as very small $\left(<1 \mathrm{~m}^{2}\right)$, small $\left(1-4 \mathrm{~m}^{2}\right)$, medium-sized $\left(4-8 \mathrm{~m}^{2}\right)$, and large patches $\left(8-15 \mathrm{~m}^{2}\right)$ (Figures 1, 2). From each class, we randomly selected 10 patches, totalizing 40 patches, covering $226 \mathrm{~m}^{2}$, reaching sample sufficiency for similar neotropical rocky outcrops (Sarthou et al. 2009; de Paula et al. 2015; Carmo and Jacobi 2016) by sampling $30 \%$ of all available patches on Piedra La Tortuga Natural Monument. All individuals found within the 40 isolated patches were identified to the species level. Abundance data was recorded according to the Braun-Blanquet approach (Braun- Blanquet 1964).

Specimens of all species were collected for posterior identification by comparison with herbarium samples, as well 


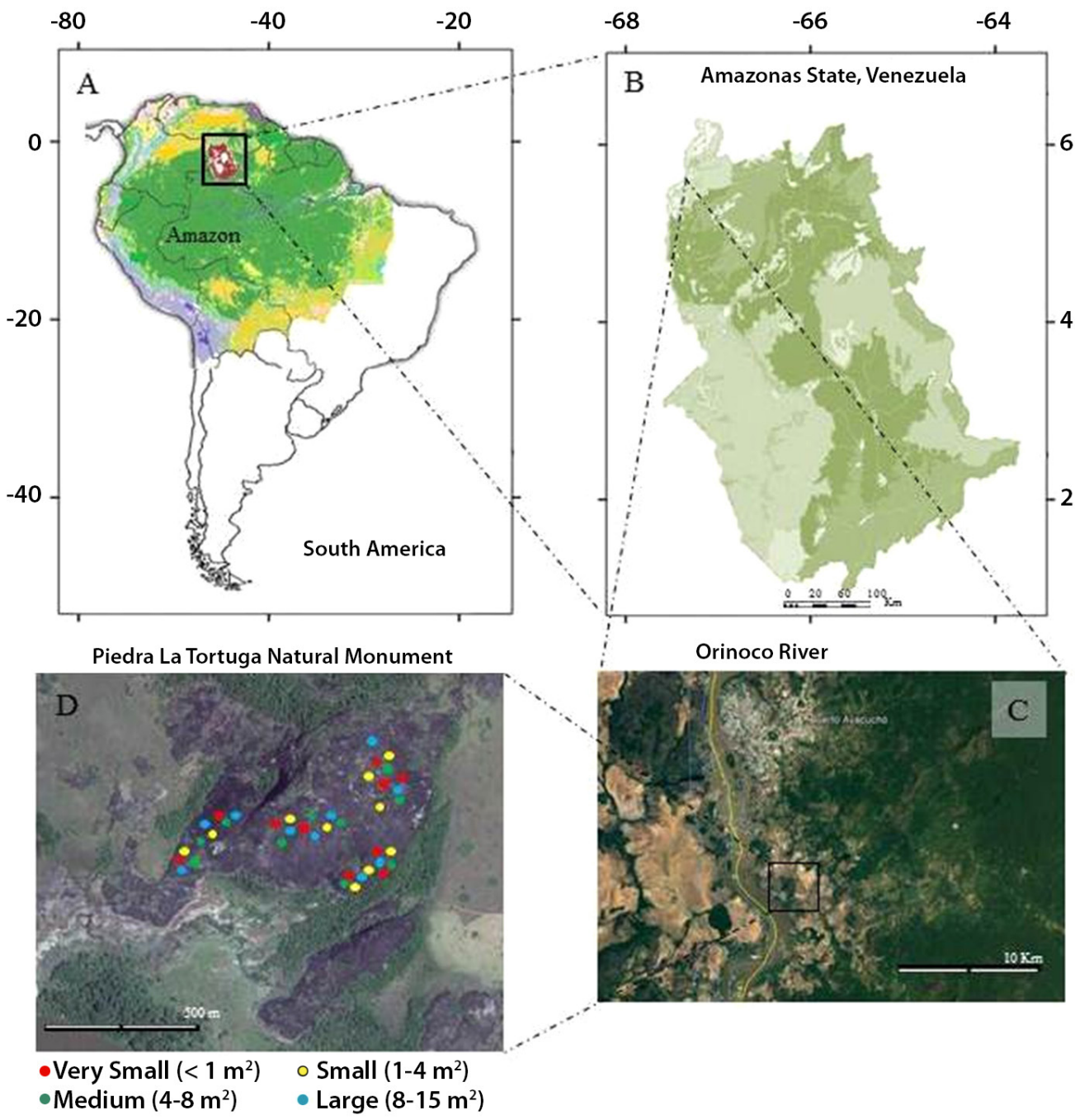

Figure 1. Location of the study area in the northern Amazon region (A), in northwestern Amazonas State, Venezuela (B). The satellite image in (C) shows the location of the Piedra La Tortuga Natural Monument (black square) on the right bank of the Orinoco River, and (D) shows the location of the 40 sampled vegetation patches within Piedra La Tortuga Natural Monument (colors indicate patch size classes). This figure is in color in the electronic version.

as by taxonomic specialists. Specimens were deposited in the Julian Steyermark Herbarium of Puerto Ayacucho (Ministry of the Environment, Amazonas State, Venezuela). Species nomenclature and their affiliation with superior taxa were checked against the current APG IV system (APG IV 2016).

\section{Data analysis}

All species found in this survey were inserted into the phylogenetic tree R20160415.new (Gastauer and Meira-Neto 2017) using the phylomatic function embedded in the Phylocom-4.2 package (Webb and Donoghue 2005). The resulting topology was calibrated using age estimates from Bell et al. (2010).

For each patch, we computed phylogenetic diversity as proposed by Faith (1992), as well as the Mean Pairwise Distance (MPD) and Mean Nearest Taxon Distance (MNTD) among distinct taxa (e.g. MPDt) and distinct individuals (e.g.,
MPDi), using Phylocom-4.2 (Webb et al. 2002). As MPD and MNTD values may be biased by species richness (Coronado $e t$ al. 2015), we also computed the Net Relatedness Index (NRI) and Nearest Taxon Index (NTI) as the negative standardized effect size transformations of all MPD and MNTD measures using the unconstrained null model, shuffling species identities 10,000 times within patches. While MPD and NRI values indicate the pattern throughout the entire phylogeny, including deep evolutionary splits, MNTD and NTI values retrieve tendencies towards the tips of the phylogeny.

Phylogenetic turnover was computed as betaMPD, betaNRI, betaMNTD, and betaNTI among all pairs of patches, as described by Fine and Kembel (2011), as the distances among different taxa (e.g. betaMPDt) and different individuals (e.g. betaMPDi). Again, betaMPD and betaMNTD might be biased to species richness, while 

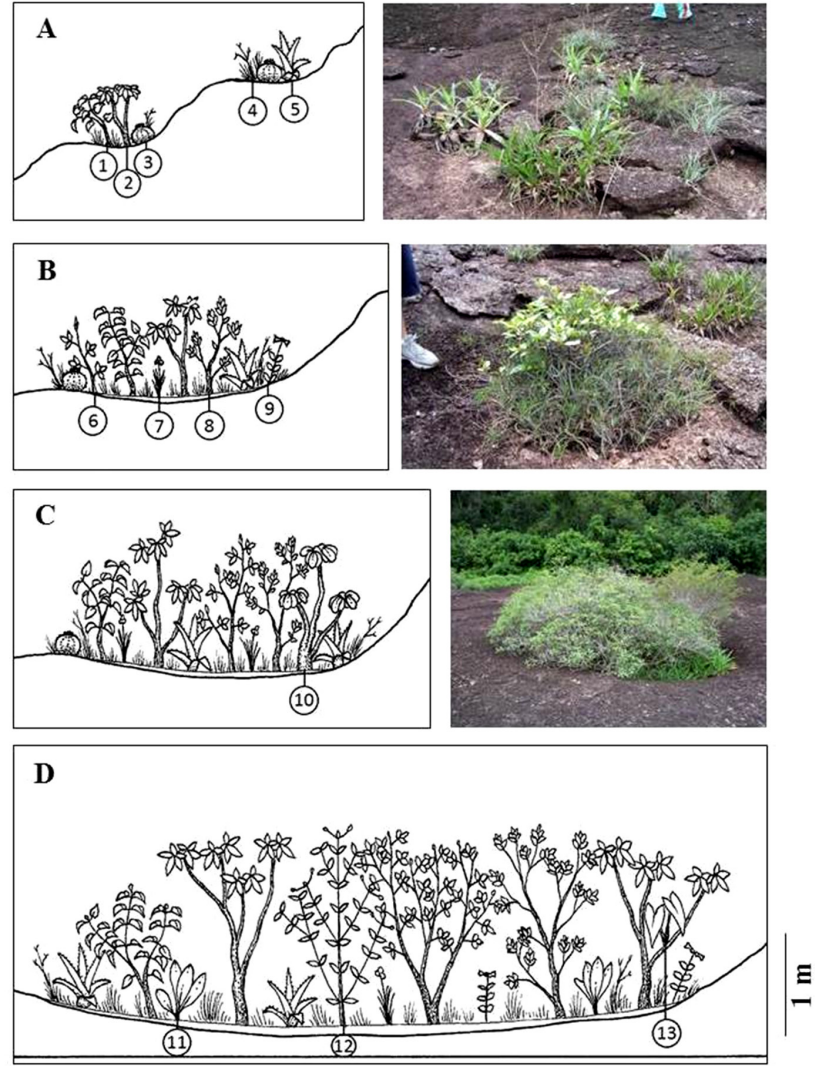

Figure 2. Examples of vegetation patches at Piedra de la Tortuga Natural Monument (Venezuela) classified according to their area as very small $\left(A_{1}<1 \mathrm{~m}^{2}\right)$, small (B, 1-4 m²), medium-sized $\left(C, 4-8 \mathrm{~m}^{2}\right)$, and large $\left(\mathrm{D}, 8-15 \mathrm{~m}^{2}\right)$. Representative species: 1) Mandevilla lancifolia, 2) Tabebuia orinocensis, 3) Melocactus mazelianus, 4) Bulbostylis leucostachya, 5) Pitcairnia armata, 6) Desmodium adscendens, 7) Cipura rupicola, 8) Acanthella sprucei, 9) Chelonanthus alatus, 10) Pseudobombax croizatii, 11) Anthurium bonplandii, 12) Commiphora leptophloes, 13) Caladium picturatum. This figure is in color in the electronic version.

computation of betaNRI and betaNTI withdraws these effects from the indices. Analogously to the computation of NRI and NTI, we randomized community composition 10,000 times for the computation of betaNRI and betaNTI values using the unconstrained null model.

To check for significant phylogenetic community structure on inselberg patches, one-tailed t-tests against zero were carried out after normalization of NRI and NTI values by $\log$ or square root transformations. Differences between large and small patches in terms of phylogenetic diversity and phylogenetic community structure were tested by one-way analysis of variance. Furthermore, relationships between patch size and phylogenetic diversity or community structure were investigated using linear models after data normalization. To outline the significance of a relationship between patch size and phylogenetic turnover, we carried out Mantel tests between the size of larger patches and the measures of phylogenetic turnover using the 'vegan' package in $\mathrm{R}$ environment version 3.2.4 ( $\mathrm{R}$ Core Team 2016).

\section{RESULTS}

In 40 patches, we found 24 species belonging to 22 genera and 19 families. All families belonged to the angiosperm clades malvids, fabids, lamiids, and monocots (Figure 3). Twelve species, i.e., $50 \%$ of all species sampled during this study, are endemic to Guiana Shield inselbergs (Table 1).

Mean NRI and NTI values varied considerably from 0.081 to 0.539 (Table 2). NTI values indicated significant clustering towards the tips of the phylogenetic tree. NRIt showed only weak phylogenetic clustering for vegetation patches from Piedra La Tortuga while NRIi showed no difference against the null expectation.

Patches larger than $4 \mathrm{~m}^{2}$ showed significantly higher species richness and PD than smaller ones (Figure 4). Only species from monocot and lamiid clades occurred in patches smaller than $2 \mathrm{~m}^{2}$, while fabids and malvids occurred in patches larger than $2 \mathrm{~m}^{2}$ (Figure 3). The results revealed higher phylogenetic overdispersion in larger patches, i.e., lower NRI and NTI values as well as higher MPD and MNTD values. Nevertheless, MPD, NRI, and NTI showed no significant differences between small and large patches (Figure 4). In contrast, MNTD was even higher in smaller patches than in larger ones (Figure 4), indicating the occurrence of a higher overdispersion in smaller patches.

Table 1. List of plant species sampled in 40 randomly selected patches at Piedra La Tortuga Natural Monument, Amazonas, Venezuela. Large patch $\left(>4 \mathrm{~m}^{2}\right)$, small patch $\left(<4 \mathrm{~m}^{2}\right)$. Endemic species are indicated with $\left(^{*}\right)$.

\begin{tabular}{|c|c|c|c|}
\hline Family & Species & $\begin{array}{l}\text { Small } \\
\text { patch }\end{array}$ & $\begin{array}{l}\text { Large } \\
\text { patch }\end{array}$ \\
\hline Apocynaceae & Mandevilla lancifolia Woodson* & $x$ & $x$ \\
\hline \multirow[t]{3}{*}{ Araceae } & Anthurium bonplandii G.S. Bunting & & $x$ \\
\hline & Caladium macrotites Schott & & $x$ \\
\hline & Caladium picturatum K. Koch \& Bouché & & $x$ \\
\hline Bignoniaceae & Tabebuia orinocensis (Sandwith) A.H. Gentry* & $x$ & $x$ \\
\hline \multirow[t]{2}{*}{ Bromeliaceae } & Pitcairnia armata Maury* & $x$ & $x$ \\
\hline & Pitcairnia pruinosa Kunth* & $x$ & $x$ \\
\hline Burseraceae & Commiphora leptophloeos (Mart.) J.B. Gillett & & $x$ \\
\hline Cactaceae & Melocactus mazelianus Říha* & $x$ & $x$ \\
\hline Clusiaceae & $\begin{array}{l}\text { Oedematopus obovatus (Spruce ex Planch. } \\
\text { \&Triana) }\end{array}$ & & $x$ \\
\hline Cyperaceae & Bulbostylis leucostachya (Kunth) C.B. Clarke* & $x$ & $x$ \\
\hline \multirow[t]{3}{*}{ Fabaceae } & Centrosema brasilianum (L.) Benth. & & $x$ \\
\hline & Desmodium adscendens var. orinocense DC.* & $x$ & $x$ \\
\hline & $\begin{array}{l}\text { Mimosa microcephala Humb. \& Bonpl. ex } \\
\text { Willd. }\end{array}$ & & $x$ \\
\hline Gentianaceae & Chelonanthus alatus (Aubl.) Pulle & $x$ & $x$ \\
\hline Iridaceae & Cipura rupicola Goldblatt \& Henrich* & $x$ & $x$ \\
\hline Lentibulariaceae & Utricularia subulata L. & & $x$ \\
\hline Malvaceae & Pseudobombax croizatii A. Robyns* & $x$ & $x$ \\
\hline \multirow[t]{2}{*}{ Melastomataceae } & Acanthella sprucei Benth. \& Hook. f.* & $x$ & $x$ \\
\hline & Pterogastra minor Naudin & & $x$ \\
\hline Ochnaceae & Sauvagesia ramosissima Spruce ex Eichler & & $x$ \\
\hline Poaceae & Thrasya paspaloides S. Denham * & & $x$ \\
\hline Portulacaceae & Portulaca pygmaea Steyerm.* & $x$ & $x$ \\
\hline Rubiaceae & Borreria pygmaea Spruce ex K. Schum.* & & $x$ \\
\hline
\end{tabular}




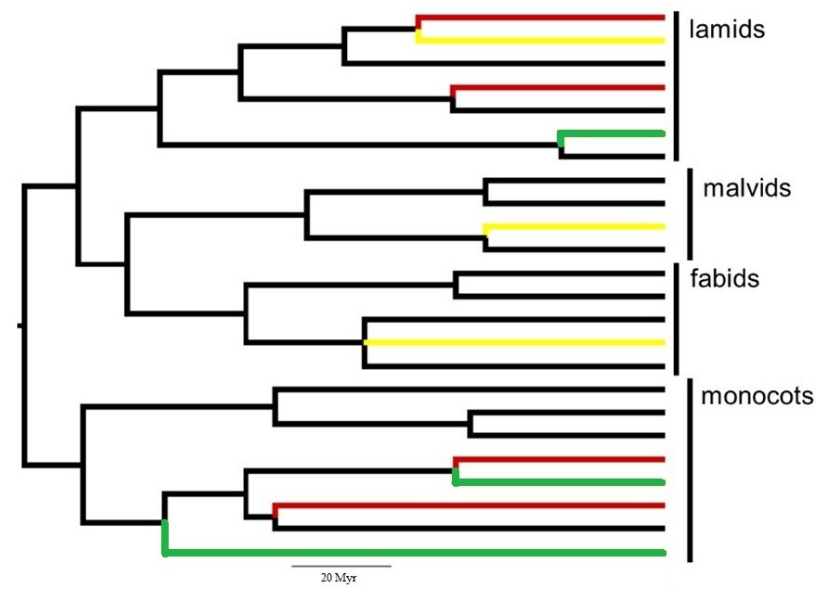

Figure 3. Phylogenetic relationships among species sampled within 40 vegetation patches on a rocky outcrop (inselberg) from Piedra La Tortuga Natural Monument, Amazonas, Venezuela. Red: taxa occurring in patches smaller than $1 \mathrm{~m}^{2}$; green: taxa found in patches smaller than $2 \mathrm{~m}^{2}$; yellow: taxa from patches smaller than $4 \mathrm{~m}^{2}$, and black: taxa restricted to patches larger $4 \mathrm{~m}^{2}$. Phylogenetic divergence scale is indicated in millions of years (Myr). This figure is in color in the electronic version.
Table 2. Phylogenetic community structure (mean values and standard deviations) in 40 rocky outcrop patches from Piedra La Tortuga Natural Monument, Amazonas, Venezuela. The $p$-value indicates the probability of observed values to differ from zero according to a one-tailed t-test after data normalization.

\begin{tabular}{lcc}
\hline Index & Mean \pm SD & $p$ \\
\hline NRIt & $0.150 \pm 0.724$ & 0.098 \\
NRli & $0.081 \pm 0.734$ & 0.245 \\
NTIt & $0.405 \pm 0.717$ & $<0.001$ \\
NTli & $0.539 \pm 0.688$ & $<0.001$ \\
\hline
\end{tabular}

NRIt is Net Relatedness Index computed among different taxa, NRli is Net Relatedness Index computed among different individuals, NTIt is Nearest Taxon Index computed among different taxa, NTli is Nearest Taxon Index computed among different individuals.

Although there were no significant relationships between measures of phylogenetic community structure and patch size, except for MNTD, all values of phylogenetic turnover showed a significant relationship with patch size according to Mantel tests, indicating the occurrence of a lower phylogenetic turnover among small patches than among larger ones (Figures 5, 6).
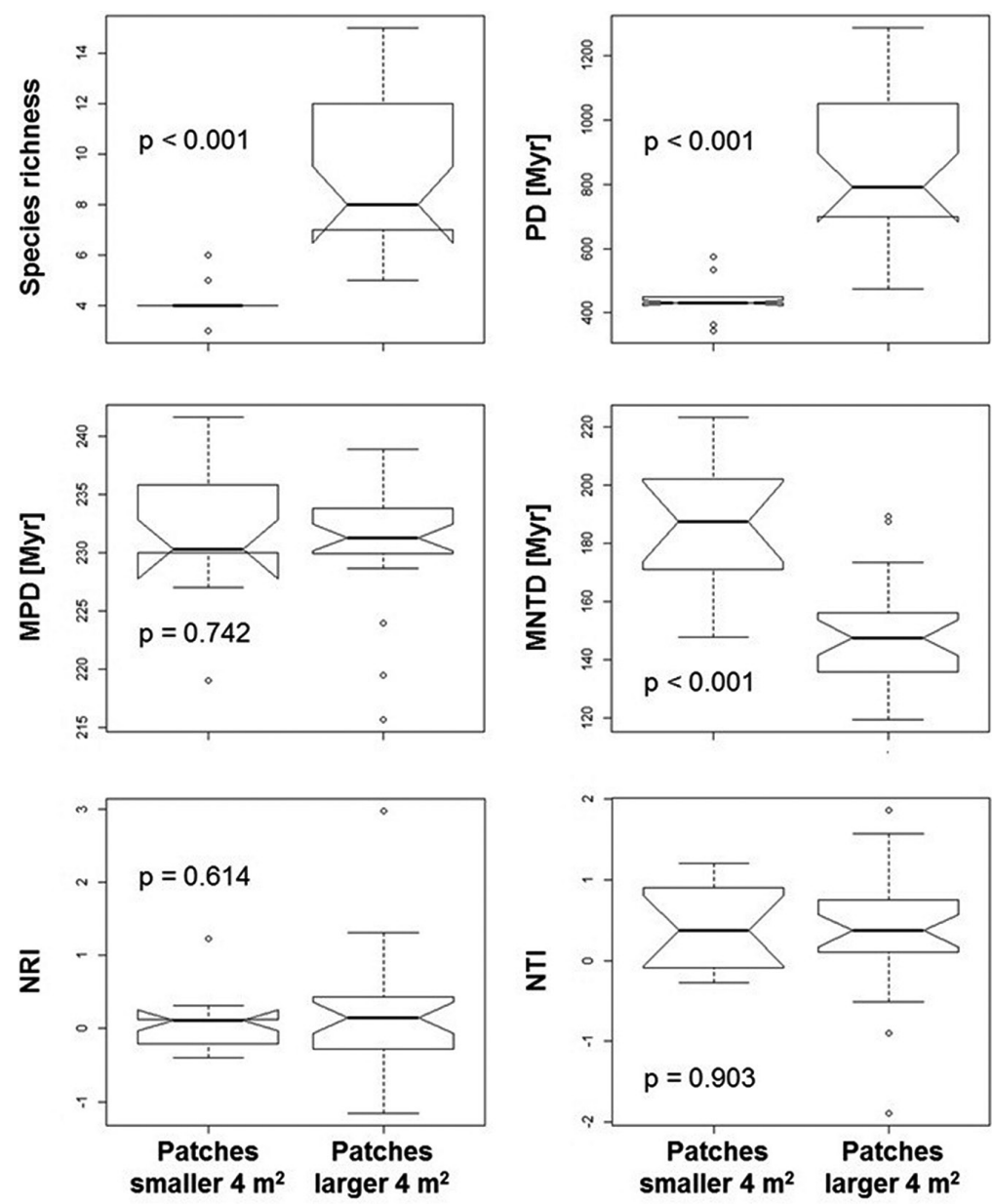

Figure 4. Differences in species richness, measures of phylogenetic diversity and community structure between small and large vegetation patches from Piedra La Tortuga Natural Monument, Amazonas, Venezuela. PD is phylogenetic diversity as defined by Faith (1992), MPD is mean pairwise distance, MNTD is mean nearest taxon distance, NRI is net relatedness index, and NTI is nearest taxon index; all indices were computed among different taxa. P values indicate significance levels of differences according to t-test after data normalization. 

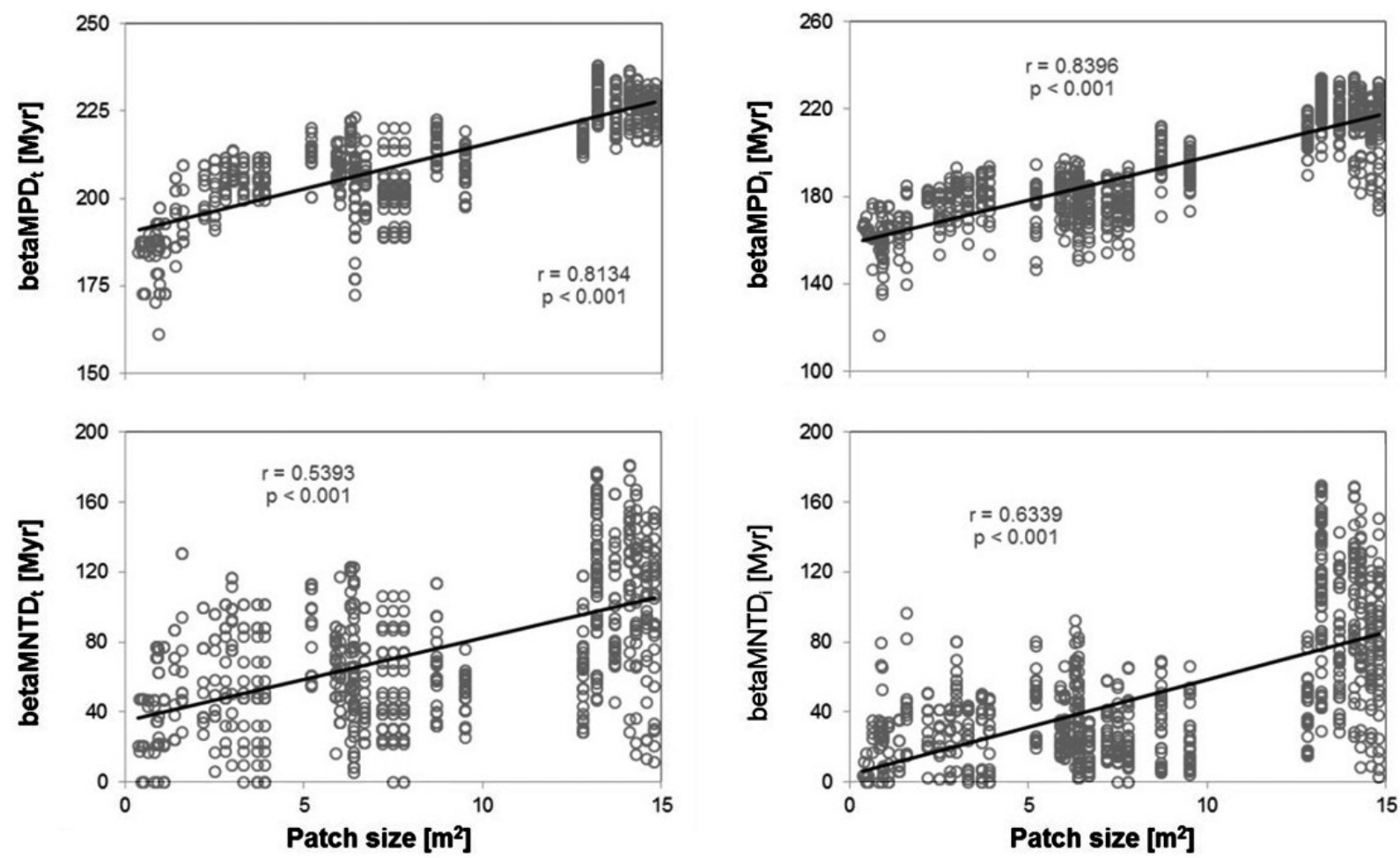

Figure 5. Phylogenetic turnover measured as mean pairwise distance among different taxa (betaMPDt) or among different individuals (betaMPDi) and mean nearest taxon distance among different taxa (betaMNTDt) or among different individuals (betaMNTDi) from pairs of communities in relation to size of the larger patch in the comparison in Piedra La Tortuga Natural Monument, Amazonas, Venezuela. Pearson's correlation coefficients ( $r$ ) and p values refer to Mantel tests.
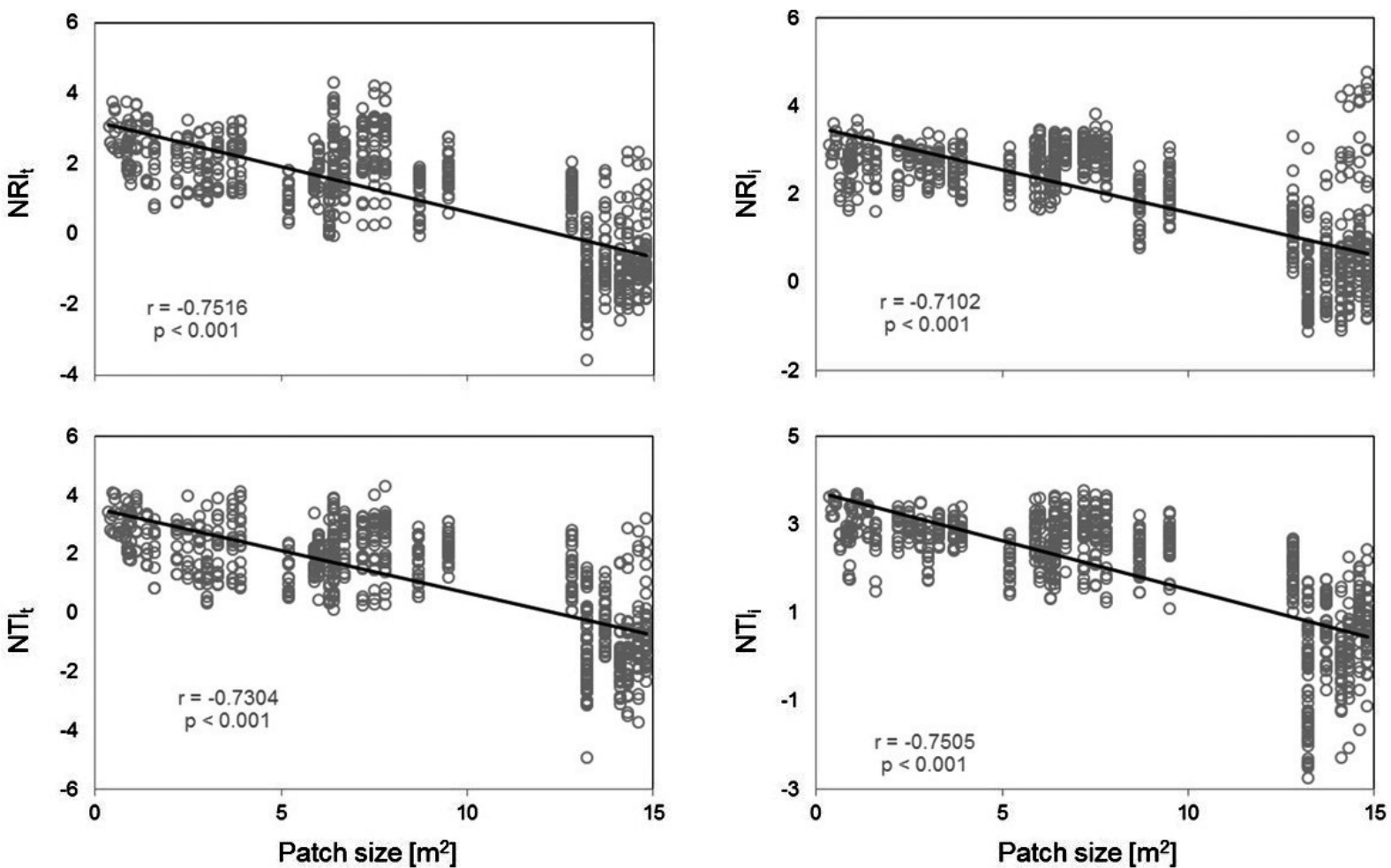

Figure 6. Phylogenetic turnover measured as net relatedness index among different taxa (betaNRIt) or among different individuals (betaNRli) and nearest taxon index among different taxa (betaNTIt) or among different individuals (betaNTli) from pairs of communities in relation to size of the larger patch in the comparison in Piedra La Tortuga Natural Monument, Amazonas, Venezuela. Pearson's correlation coefficients ( $r$ ) and p values refer to Mantel tests. 


\section{DISCUSSION}

The absence of major angiosperm clades in the phylogeny of our surveyed taxa (Figure 2) indicates that vegetation patches from rock outcrops are phylogenetically clustered. This is because species from large angiosperm clades such as campanulids, asterids, magnoliids, and rosids were not recorded in the rock outcrop patches, despite the fact that these lineages are abundant and well represented in the Venezuelan Amazonas state (Funk et al. 2007). NRI and NTI values depend on the null model used for their computation, specifically for metacommunities (Gotelli 2000). For both indices, we expected significantly positive values, indicating phylogenetic clustering, when we considered a large metacommunity containing species from other less stressful Amazonian ecosystems in our null models (Cavender-Bares et al. 2004).

Assuming that functional traits and ecological niches are conserved in evolutionary lineages, as indicated by the phylogenetic signal found in many similar studies (e.g., Moro et al. 2015; Kuhlmann and Ribeiro, 2016), our finding of phylogenetic clustering is consistent with habitat filtering in inselbergs, although it would be necessary to measure the effect of environmental filtering due to abiotic stress factors. Accordingly, to explain this phylogenetic pattern, it would be more compelling to evaluate the relative proportion of the drivers that determine community structure in the different patch sizes. Thus, our results indicate that the environmental filters that characterize the rock outcrop environment of the Piedra La Tortuga Inselberg, such as low water and nutrient availability, high radiation, and large temperature amplitudes, probably restrict species occurrence to some clades whose representatives possess certain physiological, morphological, and/or anatomical adaptations.

Our results showed that, while NRI values differed only slightly from zero, NTI values indicated strong phylogenetic clustering towards the tips of the phylogenetic tree. Different studies of phylogenetic community structure confirm this pattern (Kembel and Hubbel 2006; Gastauer and Meira-Neto 2014) and indicate the occurrence of convergent evolution towards the tips of the phylogenetic tree (Cavender-Bares et al. 2009). Nevertheless, due to the small number of species found in this study in relation to the whole Amazonas State flora (Funk et al. 2007), our findings should not be overestimated.

Our small sample size does not allow a generalization with respect to the floristic patterns on Piedra La Tortuga inselberg, yet our results indicate that species richness correlates positively with patch size on the inselberg, since larger patches had higher species richness than smaller ones. For example, different studies demonstrated that patch size was positively correlated with species richness (e.g., Kéfi et al. 2007; Svejcar et al. 2015), thus showing the same tendency where the increase in the number of observed species with increasing area sampled is one of the oldest and most general ecological patterns (Connor and McCoy 1979; Rosenzweig 1995). Nevertheless, MPD, NRI, and NTI indicated no difference in the phylogenetic structure between large and small patches; therefore, no conclusion on the strength of environmental filters in relation to patch size may be drawn from these indices. In contrast, the higher MNTD might indicate phylogenetic overdispersion in small plots, and phylogenetic clustering in large ones, but before this conclusion can be safely drawn, the relationship between MNTD and species richness should be considered (Coronado et al. 2015). Therefore, the observed patterns of MNTD may have resulted from differences in species richness between small and large patches. Overall richness of the Piedra La Tortuga inselberg might have been underestimated due to our reduced sample size. Further sampling might increase overall species richness, but we do not expect an alteration in the detected positive relation between patch size and species richness, which is generally known as the species-area relationship, and is a well-established ecological principle (e.g. Kéfi et al. 2007).

The increased phylogenetic turnover with increasing patch size indicates that the species pool from smaller patches is phylogenetically more related than that from larger ones. As outlined above, the measures of betaMPD and betaMNTD may be biased by species richness. Thus, when the effect of species richness is eliminated, results on phylogenetic turnover indicate that smaller patches are phylogenetically more clustered than larger ones. This shows the high applicability of phylogenetic turnover to reveal the pattern of phylogenetic clustering or overdispersion in small datasets, where the indices of phylogenetic community structure do not have sufficient statistical support. Furthermore, assuming niche conservation in evolutionary lineages, our findings indicate that species from smaller patches are functionally more similar and show higher niche overlap than species from larger patches. This particular finding is consistent with the hypothesis of occurrence of lower environmental stress in larger patches (Svejcar et al. 2015), while smaller patches can be occupied by adaptive taxa from few clades. In this scenario, higher phylogenetic dispersion in larger patches is likely due to the higher magnitude of biotic interactions in comparison with smaller patches. However, these patterns need to be further explored in future studies.

\section{CONCLUSIONS}

Our results indicate the occurrence of phylogenetic clustering in vegetation patches on a rocky outcrop from a Neotropical inselberg, the Piedra La Tortuga Natural Monument. Phylogenetic distribution of taxa, as well as patterns of phylogenetic turnover among patches, are consistent with a scenario of higher environmental stress in smaller patches, thus it would be important to better evaluate whether facilitation is the major driver in plant assemblages of larger patches. 
Vegetation patch size is a component of habitat structure on rock outcrops and is also a potential factor determining species assemblage in inselberg vegetation. Thus the identification of nurse species is of primary interest in inselberg vegetation patches, which are pivotal units for conservation and restoration of inselberg ecosystems.

\section{ACKNOWLEDGMENTS}

The authors thank the Hivi's Indigenous Community for allowing the research in its traditional area, the Organization of American States (OAS) and the Coordenação de Aperfeiçoamento de Pessoal de Nível Superior (CAPES, Brazil), for granting a scholarship to the first author. We are grateful to an anonymous reviewer for important comments on this manuscript.

\section{REFERENCES}

Aguiar, W.M.; Gaglianone, M.C. 2011. Euglossine bees (Hymenoptera, Apidae, Euglossina) on an inselberg in the Atlantic Forest Domain of southeastern Brazil. TropicalZoology, 24: 107-125.

APG IV. 2016. An update of the Angiosperm Group classification for the orders and families of flowering plants: APG IV. Botanical Journal of the Linnean Society, 141:399-436.

Bell, C.D.; Soltis, D.E.; Soltis, P.S. 2010. The age and diversification of the angiosperms re-revisited. American Journal of Botany, 97: 1296-1303.

Braun-Blanquet, J. 1979. Fitosociologia. Bases para el estudio de las comunidades vegetales. $\mathrm{H}$. Blume Ediciones, Madrid, 820p.

Bruno, J.F.; Stachowicz, J.J.; Bertness, M.D. 2003. Inclusion of facilitation into ecological theory. Trends in Ecology and Evolution, 18: 119-125.

Bowker, M.A.; Maestre, F.T. 2012. Inferring local competition intensity from patch size distributions: a test using biological soil crusts. Oikos, 121: 1914-1922.

Bussell, J.D.; James, S.D. 1997. Rocks as museums of evolutionary processes. Journal of the Royal Society of Western Australia, 80: 221-230.

Carmo, F.F.; Jacobi, C.M. 2016. Diversity and plant trait-soil relationships among rock outcrops in the Brazilian Atlantic rainforest. Plant Soil, 403:7-20

Carrión, J.F.; Gastauer, M.; Mesquita, N.; Meira-Neto J.A.A. 2017. Facilitation as a driver of plant assemblages in Caatinga. Journal of Arid Environments, 142: 50-58

Cavender-Bares, J.; Ackerly, D.D.; Baum. D.A.; Bazzaz. F.A. 2004. Phylogenetic overdispersion in Floridian oak communities. The American Naturalist, 163: 823-843.

Cavender-Bares, J.; Kozak, K.H.; Fine, P.V.A.; Kembel, S.W. 2009. The merging of community ecology and phylogenetic biology. Ecology Letters, 12: 693-715.

Cianciaruso, M.V.; Silva, I.A.; Batalha, M.A. 2009. Diversidades filogenética e funcional: novas abordagens para a Ecologia de comunidades. Biota Neotropica, 9: 93-103.
Connor, E.F.; McCoy, E.D. 1979. The statistics and biology of the species-area relationship. The American Naturalist, 113: 791-833.

Coronado, E.N.H.; Dexter, K.G.; Pennington, R.T.; Chave, J.; Lewis, S.L. 2015. Phylogenetic diversity of Amazonian tree communities. Diversity and Distributions, 21: 1295-1307.

de Paula, L.F.A.; Negreiros, D.; Azevedo, L.O.; Fernandes, R.L.; Stehmann, J.R.; Silveira, F.A.O. 2015. Functional ecology as a missing link for conservation of a resource-limited flora in the Atlantic forest. Biodiversity and Conservation, 24: 2239-2253.

Faith, D.P. 1992. Conservation evaluation and phylogenetic diversity. Biological Conservation, 61: 1-10.

Fine, P.V.A.; Kembel, S.P. 2011. Phylogenetic community structure and phylogenetic turnover across space and edaphic gradients in western Amazonian tree communities. Ecography, 34: 552-565.

Funk, V.; Hollowell, T.; Berry, P.; Kelloff, C.; Alexander, S.N. 2007. Checklist of the plants of the Guiana Shield (Venezuela: Amazonas, Bolivar, Delta Amacuro; Guyana, Surinam, French Guiana). Contributions from the United States National Herbarium, 55: 1-584.

García-Cervigón, A.I.; Linares, J.C.; Aibar, P.; Olano, J.M. 2015. Facilitation promotes changes in leaf economics traits of a perennial forb. Oecologia, 179: 103-116.

Gastauer, M.; Meira-Neto, J.A.A. 2014. Interactions, environmental sorting and chance: phylostructure of a tropical forest assembly. Folia Geobotanica, 49: 443-459.

Gastauer, M.; Meira-Neto, J.A.A. 2017. Updated angiosperm family tree for analyzing phylogenetic diversity and community structure. Acta Botanica Brasilica, 31:191-198.

Gotelli, N.J. 2000. Null model analysis of species co-occurrence patterns. Ecology, 81: 2606-2621.

Greilhuber, J.; Borsch., T.; Müller, K.; Worberg, A.; Porembski, S.; Barthlott, W. 2008. Smallest angiosperm genomes found in Lentibulariaceae, with chromosomes of bacterial size. Plant Biology, 8: 770-777.

Gröger, A. 2000. Flora and vegetation of inselbergs of Venezuelan Guayana. In: Porembski, S.; Barthlott, W. (Ed.). Inselbergs: biotic diversity of isolated rock outcrops in tropical and temperate regions. Ecological studies. v.146. Springer-Verlag Berlin Heidelberg, New York, p.291-314.

Gröger, A.; Huber, O. 2007. Rock outcrop habitats in the Venezuelan Guayana lowlands: their main vegetation types and floristic components. Revista Brasileira de Botânica, 30: 599-60.

Hardy, O.J.; Jost, L. 2008. Interpreting and estimating measures of community phylogenetic structuring. Journal of Ecology, 96: 849-852.

Huber, O. 1995. Conservation of the Venezuelan Guayana. In: Steyermark, J.A.; Berry, P.E.; Holst, B.K. (Ed.). Flora of the Venezuelan Guayana. v.1. Missouri Botanical Garden Press, Portland, Oregon, p.20-230.

Jocque, M.; Vanschoenwinkel, B.; Brendonck, L. 2010. Freshwater rock pools: a review of habitat characteristics, faunal diversity and conservation value. Freshwater Biology, 55: 1587-1602.

Kéfi, S.S.; Rietkerk, M.; Alados, C.L.; Pueyo, Y.; Papanastasis, V.P.; ElAich, A.; de Ruiter, P.C. 2007. Spatial vegetation patterns 
and imminent desertification in Mediterranean arid ecosystems. Nature, 449: 213-217.

Kembel, S.W.; Hubbell, S.P. 2006. The phylogenetic structure of a neotropical tree community. Ecology, 87: 86-99.

Kraft, N.J.B.; Adler, P.B.; Godoy, O.; James, E.C.; Fuller, S.; Levine, J.M. 2015. Community assembly, coexistence and the environmental filtering metaphor. Functional Ecology, 29: 592-599.

Kuhlmann, M.; Ribeiro, J.F. 2016. Fruits and frugivores of the Brazilian Cerrado: ecological and phylogenetic considerations. Acta Botanica Brasilica, 30: 495-507.

McIntire, E.J.B.; Fajardo, A. 2014. Facilitation as a ubiquitous driver of biodiversity. New Phytologist, 201: 403-416.

Moro, M.F.; Silva, I.A.; Araújo, F.S.; Lughadbha, E.N.; Meagher, T.R.; Martins, F.R. 2015. The role of edaphic environment and climate in structuring phylogenetic pattern in seasonally dry tropical plant communities. PLoS ONE, 10: e0119166.

Pessanha, A.S.; Menini, N.L; Forzza, R.C.; Nascimento, M.T. 2014. Composition and conservation of Orchidaceae on an inselberg in the Brazilian Atlantic Forest and floristic relationships with areas of Eastern Brazil. International Journal of Tropical Biology, 62: 829-841.

Porembski, S.; Barthlott, W. 2000. Inselbergs: biotic diversity of isolated rock outcrops in tropical and temperate regions. Springer-Verlag Berlin Heidelberg, New York, 542p.

Porembski, S. 2007. Tropical inselbergs: habitat types, adaptive strategies and diversity patterns. Revista Brasileira de Botânica, 30: 579-586.

Porembski, S.; Silveira, F.O.A.; Fiedler., P.L.; Watve, A.; Rabarimanarivo, M., Kouame. F.; Hopper, S.D. 2016. Worldwide destruction of inselbergs and related rock outcrops threatens a unique ecosystem. Biodiversity and Conservation, 25: 2827-2830.

Pugnaire, F.I.; Lázaro, R. 2000. Seed bank and understorey species composition in a semi-arid environment: the effect of shrub age and rainfall. Annals of Botany, 86: 807-813.

R Core Team. 2016. R: a language and environment for statistical computing. R Foundation for Statistical Computing, Vienna, Austria (https://www.R-project.org/).
Rosenzweig, M.L. 1995. Species diversity in space and time. Cambridge University Press, Cambridge, 436p.

Sarthou, C.; Kounda-Kiki, C.; Vaçulik, A.; Mora, P.; Ponge, J.F. 2009. Successional patterns on tropical inselbergs: a case study on the Nouragues inselberg (French Guiana). Flora, 204: 396-407.

Seine, R.; Porembski, S.; Barthlott, W. 1995. A neglected habitat of carnivorous plants: inselbergs. Feddes Repertorium, 106: 555-562.

Silva, D.M.; de Paula, L.P.; Rosatti, N.B.; Silva, I.A.; Cianciaruso, M.V.; Batalha, M.A. 2011. Os efeitos dos regimes de fogo sobre a vegetação de Cerrado no Parque Nacional das Emas, GO: considerações para a conservação da diversidade. Biodiversidade Brasileira, 2: 26-39.

Simberloff, D.S. 1970. Taxonomic diversity of island biotas. Evolution, 24: 23-47.

Stachowicz, J.J. 2001. Mutualism, facilitation, and the structure of ecological communities. BioScience, 51: 235-246.

Svejcar, L.N.; Bestelmeyer, B.T.; Duniway, M.C.; James, D.K. 2015. Scale-dependent feedbacks between patch size and plant reproduction in desert grassland. Ecosystems, 18: 146-153.

Valiente-Banuet, A.; Verdú, M. 2013. Plant facilitation and phylogenetics. Annual Review of Ecology, Evolution, and Systematics, 44: 347-366.

Vogiatzakis, I.N.; Kazakis, G.; Ghosn, D. 2009. Macrophyte community structure and species occurrence in relation to environmental determinants in the ephemeral aquatic habitats of Gavdos, Greece. Hydrobiologia, 630: 127-138.

Webb, C.O.; Ackerly, D.D.; McPeek, M.A.; Donaghue, M.J. 2002. Phylogenies and community ecology. Annual Review of Ecology and Systematics, 33: 475-505.

Webb, C.O.; Donoghue, M.J. 2005. Phylomatic: tree assembly for applied phylogenetics. Molecular Ecology Notes, 5: 181-183.

Winemiller, K.O.; Fitzgerald, D.B.; Bower, L.M.; Pianka, E.R. 2015. Functional traits, convergent evolution, and periodic tables of niches. Ecology Letters, 18: 737-751.

RECEIVED: $16 / 12 / 2017$

ACCEPTED: 02/03/2018

ASSOCIATE EDITOR: Ricarda Riina 